\title{
Telenursing manual for providing care to patients using clean intermittent urinary catheterization
}

\author{
Manual de telenfermagem para atendimento ao usuário de cateterismo urinário intermitente limpo \\ Manual de teleenfermería para la atención al usuario de cateterismo urinario intermitente limpio
}

Valtuir Duarte de Souza-Junior ${ }^{1}$ Isabel Amélia Costa Mendes ${ }^{1}$ Alessandra Mazzo ${ }^{1}$

Cristiano Alves dos Santos ${ }^{2}$

Elaine Maria Leite Rangel Andrade ${ }^{3}$ Simone de Godoy ${ }^{1}$

\section{Universidade de São Paulo.}

Ribeirão Preto, São Paulo, Brazil.

2. Hospital Sírio-Libanês. São Paulo,

São Paulo, Brazil.

3. Universidade Federal do Piauí.

Teresina, Piauí, Brazil.
Correspondence author: Isabel Amélia Costa Mendes. E-mail: iamendes@usp.br

Submitted on 07/07/2017. Accepted on 09/05/2017.

DOI: 10.1590/2177-9465-EAN-2017-0188

\section{Abstract}

Objective: To develop and evaluate apparent and content validity of a telenursing manual to support nurses in the care delivery of patients using clean intermittent urinary catheterization. Methods: Methodological study addressing the development and validation of a telenursing manual. The expert group who validated the telenursing manual was composed of 11 nurses. An inter-rater level of agreement of $70 \%$ was considered for each aspect of the instrument. Results: The following levels of agreement were obtained for each aspect: Language $97 \%$, Content $97.7 \%$ and Objectives, Relevance, Functionality and Usability $100 \%$ each. Conclusion: The manual is available for access and represents an important initiative for the field of telenursing in Brazil, assisting nurses in the telecare provided to patients using clean intermittent urinary catheterization.

Keywords: Telenursing; Urinary Bladder, Neurogenic; Intermittent Urethral Catheterization; Urinary Catheterization; Telephone.

\section{Resumo}

Objetivo: Elaborar e validar em aparência e conteúdo um manual de telenfermagem para subsidiar o enfermeiro no atendimento ao cliente com bexiga neurogênica, usuário de cateterismo urinário intermitente limpo. Método: Estudo metodológico sobre a construção e validação de manual de telenfermagem. O manual foi validado em aparência e conteúdo por 11 enfermeiros peritos para tanto, considerou-se válido cada aspecto do instrumento que atingiu o nível mínimo de concordância de $70 \%$ entre os peritos. Resultados: O manual obteve, para cada aspecto avaliado, os seguintes níveis de concordância - Linguagem: 97\%; Conteúdo: 97,7\%; e Objetivos, Funcionalidade, Usabilidade e Relevância: 100\% cada. Conclusão: O manual encontra-se disponível para acesso e representa uma iniciativa importante para o campo da telenfermagem no Brasil, auxiliando o enfermeiro na realização do teleatendimento e atendimento ao usuário de cateterismo urinário intermitente limpo.

Palavras-chave: Telenfermagem; Bexiga Urinária Neurogênica; Cateterismo Uretral Intermitente; Cateterismo Urinário; Telefone.

\section{Resumen}

Objetivo: Elaborar y validar la apariencia y el contenido de un manual de teleenfermería para apoyar al enfermero en la atención al cliente que usa catéter urinario intermitente limpio. Método: Estudio metodológico sobre la construcción y validación de manual de teleenfermería. La apariencia y el contenido del manual fueron validados por 11 enfermeros peritos, considerando para validación un nivel de concordancia del $70 \%$ entre los peritos para cada aspecto del instrumento utilizado. Resultados: El manual de teleenfermería fue validado en apariencia y contenido considerando el nivel de concordancia entre los peritos para cada uno de estos aspecto: Lenguaje 97\%; Contenido 97,7\%; y, Objetivos, Relevancia, Funcionalidad y Usabilidad 100\% cada uno. Conclusiones: El manual está disponible para ser accedido y representa una iniciativa importante para el campo de la teleenfermería en Brasil, ayudando al enfermero en la práctica de la teleatención al usuario de cateterismo urinario intermitente limpio.

Palabras clave: Teleenfermería; Vejiga Urinaria Neurógena; Cateterismo Uretral Intermitente; Cateterismo Urinario; Teléfono. 


\section{INTRODUCTION}

Telenursing incorporates telehealth and is characterized by the use of technological resources to enable the practice of nursing at a distance in terms of care, education and research. The access of nurses to patients is facilitated so that nurses can monitor and assist patients, encouraging self-care, while saving time and resources. ${ }^{1}$

Research addressing telenursing is expanding internationally and indicates the potential of this resource to promote health - especially in countries with large geographical areas and to support the treatment of patients with acute or chronic problems. ${ }^{2-6}$ Some countries have already integrated telenursing into healthcare services, especially the use of the telephone..$^{6-8}$

In Brazil, telenursing was initiated in 2000 with the pioneering work conducted by the GEPECOPEn (Study and Research Group on Communication in the Nursing Process). The group used information and communication technologies to support the brick-and-mortar teaching of undergraduate and graduate programs and also of continuing nursing education. ${ }^{9}$

$A$ recent and important measure in the field of telenursing in Brazil was Substantiated Guidance No. 016/2017, from the Technical Chamber of the Regional Council of Nursing of the state of São Paulo. Such a measure establishes that qualified nurses using adequate resources can not only provide nursing teleconsultations, but also contribute to other activities resulting from this knowledge. ${ }^{10}$

In this context, telenursing can be crucial to advising patients regarding self-care ${ }^{11}$ and can support nurses providing care to individuals with neurogenic bladder (NB) using clean intermittent catheterization $(\mathrm{CIC})$. The use of telenursing for this purpose was not identified in a recent integrative literature review. ${ }^{6}$

NB is a chronic disorder, caused by damage in the nervous system, which leads to changes in one's micturition pattern in the filling and emptying phases of the bladder. Complications accruing from NB range from minimal to the most complex alterations, and may present different forms, among which are: increased intravesical pressure; incomplete emptying of the bladder; lack of urination reflex; or urinary incontinence. ${ }^{12}$

Clean intermittent catheterization is the choice to treat bladder dysfunctions, in which urination no longer meets the demand for bladder emptying. This procedure can be implemented in patients at any age, even children and newborns. $\mathrm{CIC}$ allows emptying the bladder periodically with the use of the catheter, which can be introduced through the urethra or continent stoma (surgically created when the urethra is compromised). This procedure allows for the complete emptying of the bladder, helping preserving the urinary tract; i.e., there is no need for keeping the catheter inserted, which prevents greater complications, such as increased urinary tract infection rates. ${ }^{13,14}$

The CIC technique, in which the patient can perform the procedure, was first described in the literature ${ }^{15}$ in 1972 . The technique is performed after washing hands and the perineal area with water and soap only; no antiseptic or sterile gloves are needed. Sterile gloves are used by caregivers/healthcare workers performing the procedure for their own protection, therefore, are considered personal protective equipment (PPE). Patients can introduce CIC when lying down, sitting or standing; women may use a mirror to assist in seeing the urethral meatus. ${ }^{14,16,17}$

Patients requiring the use of $\mathrm{CIC}$ may have difficulty accepting the procedure and, as a result, experience a change in self-image, experience loss of independence, alter their social habits, and may develop barriers, requiring assistance to adapt. Therefore, for the treatment to be effective, it needs to be planned properly and take into account all factors, i.e., psychosocial, cultural, political and economic factors, a situation that represents a great challenge for health workers providing care to these patients. ${ }^{18,19}$

Many patients performed the CIC by themselves and faced difficulties performing it with the correct technique and recommended frequency. Usually, they were patients with a low educational level and low economic level. The main medical diagnoses found among these patients were spinal cord trauma and myelomeningocele. Patients with neurogenic bladder with spinal cord injury faced greater difficulties related to mobility and accessibility, as total physical immobility may occur depending on the site of injury. ${ }^{18,20}$

It is essential that patients using $\mathrm{CIC}$ have the opportunity to be advised by the nursing staff in their homes in a dynamic way, with improved access to nursing care to implement their treatment and the CIC. In Brazil, however, there is a lack of material addressing telenursing in the care of patients in general, let alone material directed to patients with NB using CIC.

Given the previous discussion, this study's objective was to develop a telenursing manual and perform its apparent and content validation to support nurses in the delivery of care to patients with NB using $\mathrm{CIC}$.

\section{METHOD}

This is a methodological study addressing the development and validation of a telenursing manual regarding the care of patients with $\mathrm{CIC}$. The manual is available at the GEPECOPEn website. ${ }^{21}$ Three steps were implemented:22 (1) a search in the literature for scientific knowledge addressing this subject, such as concepts, procedures, care actions, and resources; (2) adapting the language found in the literature to the manual's target public, intending to make it more objective, attractive, and efficient; (3) qualification of the material produced.

Data collection was initiated after the study project was approved by the Institutional Review Board (Report 105/2013) and after the study's participants consented and signed free and informed consent forms. 


\section{Development of the Telenursing Manual}

The manual's objectives included: providing a theoretical foundation upon which nurses can rely to develop teleassistance for patients with NB using $\mathrm{CIC}$; synthesize information and communication technologies so that nurses can integrate care transcending the barriers of health services; and provide guidance in the use of communication tools to associate them with teleassistance.

The search for material to develop the telenursing manual in order to meet these objectives was initially conducted with the contextualization of the theme in Brazil and overseas, after which a theory that would aid in the implementation of teleassistance to patients was selected (Orem's Self-Care Theory), ${ }^{23}$ and orientation regarding the care necessary when providing teleassistance (principles of nursing teleassistance), was identified. ${ }^{24}$ Afterwards, some technological resources available in Brazil were selected so nurses could identify the most feasible ones to reach their patients. A search was conducted for evidence concerning health care provided to patients with NB to assist the use of $\mathrm{CIC}$.

The manual was developed to help nurses, but any member of the nursing or health staff may consult it, especially as the manual was developed with clear language and included images in order to enable pleasurable reading and good understanding of content, to encourage the practice of consulting it.

\section{Selection of experts}

The criteria proposed by Fehring ${ }^{25}$ were employed to select a group of experts. These criteria consider an expert to be a professional with a minimum of a Master's degree, scoring at least 5 points (from a total of 14). The score is distributed as follows: Master's degree in nursing (4 points), Master's thesis addressing the study's field of interest (1 point); doctoral dissertation in the study's field of interest (2 points); clinical practice with one or more years of experience in the study's field of interest (1 point); specialization in the study's field of interest (2 points); publication of relevant study in the field of interest (2 points); and publication of papers in refereed periodicals addressing the study's field of interest (2 points).

Eleven nurses experts performed the apparent and content validation of the telenursing manual. The nurses invited to participate in the study were affiliated with higher education institutions and/or urology rehabilitation centers, working in the following fields and topics of interest: Fields of interest - basic procedures for nursing care provided in situations of hospitalization, outpatient situations, and/or for the training of human resources in the field of nursing associated with the use of information and communication technologies (e.g., Internet, distance education, virtual learning environments, videoconferences). Topics of interest - nursing assistance to patients with urinary elimination problems and the development of human resources in the field of nursing for professional qualification. After a prior assessment of the nurses' resumes, they were asked in person or through email if they were interested in participating in a group of experts to assess the manual.

An odd number of experts is advisable to avoid a tie when making assessments. The number of experts participating in the study was based on an approximate number provided in the study conducted by Ferreira. ${ }^{26}$ The experts who consented to participate received the material to be evaluated, in print or virtual format according to their preference, with a deadline of up to 15 days to return the material to the researchers. The manual was also assessed by the researchers in a teleassistance intervention implemented among patients with NB using CIC.

\section{Data collection}

The manual was qualified through validation conducted by nursing experts using an instrument that was based on the one developed by Ferreira. ${ }^{26}$ The apparent and content validation of the instrument was performed by a group of three experts, whose suggestions were implemented. The instrument has a Likert scale with the following items: "Strongly agree" (SA), "Agree" (A), "Disagree" (D), "Strongly disagree" (SD), and "I do not know" (IDK). After reading the manual, the expert would check a level of agreement according to his/her assessment of the manual's items. The aspects of the manual assessed by the experts included: objectives, content, language, relevance, functionality, and usability.

\section{Data analysis}

Data were analyzed using descriptive statistics (frequency and percentage) via the Statistical Package for Social Science (SPSS), version 15.0. The manual was considered to be validated when a level of agreement of $70 \%$ was achieved among the experts for each aspect of the instrument. 27,28 The manual was submitted to publication after the experts' suggestions were implemented.

\section{RESULTS}

Among the experts who validated the telenursing manual, 11 were nurses affiliated with five (federal and state) higher education institutions located in four Brazilian states, while one was affiliated with an institution located overseas. Nine (81.8\%) were female and two (18.2\%) were male professionals, aged between 25 and 59 years old, an average age of 38.4 years (median 35 and standard deviation of 10.37), while most experts (six) were aged between 30 and 40 years old.

Time since graduation ranged from 3 to 38 years, with an average of 15.4 years (median 13 and standard deviation equal to 10.39), while most had graduated between 10 and 20 years ago (six experts). Regarding the field of professional practice, 
six $(54.5 \%)$ were professors, one of whom was attending a graduate program, three $(27.3 \%)$ worked in the field of research and extension, one $(9.1 \%)$ was exclusively a graduate student, and one $(9.1 \%)$ expert worked in research support. The experts' experience ranged from six months to 38 years; four experts $(36.4 \%)$ presented up to two years of work experience; four $(36.4 \%)$ presented from 8 to 14 years, while three experts (27.3\%) presented from 20 to 38 years of work experience.

In regard to their occupation, ten $(90.9 \%)$ provided care in a medical clinic, a surgical clinic, a family health team, critical care nursing, child and adult urology, a kidney transplantation unit, neurosurgery intensive unit, emergency care, committee of hospital infection control, and psychiatry.

Six experts $(54.5 \%)$ had attended a specialization program, among which were rehabilitation nursing, neuropediatrics, emergency services, prevention and control of infection in health services, critical care nursing, and occupational health nursing.

Ten $(90.9 \%)$ of the experts had a Master's degree in nursing and one had a Master's degree in education; five (45.5\%) had a doctoral degree in nursing, and one $(9.1 \%)$ was a postdoctorate in nursing. The scores, according to criteria proposed by Fehring, ${ }^{25}$ were established as: four (36.4\%) experts scored 5 points, two (18.2\%) scored 6; one (9.1\%) scored 7; two (18.2\%) scored 9 ; one $(9.1 \%)$ scored 10 ; and one (9.1\%) scored 12 points. The distribution of the experts' answers regarding the instrument validating the telenursing manual is presented in Table 1.

\section{DISCUSSION}

The development of documents suitable to supporting the practice of telenursing when providing care to patients is essential to providing nurses conditions under which organized and systematized care is practicable, promoting the expansion and strengthening of telenursing, especially in countries where this practice is not yet consolidated. The development and validation of a telenursing manual to offer such support to nurses when using telenursing to provide care to patients with NB using $\mathrm{CIC}$ is an important measure, a strategy to complement the care provided to this population in its rehabilitation process.

The development of educational material or protocols ${ }^{29,30}$ that assist and systematize the practice of nursing is essential to ensuring improved quality of health care and is a way to encourage the search for qualification on the part of professionals to perform qualified care. Additionally, it aids in the teaching-learning process and in the dissemination of knowledge, essential for the development of nursing.

A landmark for telehealth in Canada was the National Initiative for Telehealth Framework of Guidelines, financed by the Richard Ivey Foundation. It is a document that is the result of a national action with interdisciplinary collaboration in five areas within telehealth: Clinical Standards and Outcomes; Human Resources; Organizational Readiness; Organizational Leadership; and Technology and Equipment. ${ }^{31}$ Another Canadian

Table 1. Distribution of experts' answers regarding the aspects of the instrument validating the telenursing manual

\begin{tabular}{|c|c|c|c|c|c|}
\hline Item & $S A-N(\%)$ & $A-N(\%)$ & $D-N(\%)$ & SD - N (\%) & IDK - N (\%) \\
\hline \multicolumn{6}{|l|}{ Objective } \\
\hline a) The manual's objective are appropriate & $6(54.5)$ & $5(45.5)$ & - & - & - \\
\hline $\begin{array}{l}\text { b) The manual's objectives are coherent with nursing } \\
\text { practice }\end{array}$ & $8(72.7)$ & $3(27.3)$ & - & - & - \\
\hline Total of answers $(\mathrm{N}=\mathbf{2 2})$ & $14(63.6)$ & $8(36.4)$ & - & - & - \\
\hline \multicolumn{6}{|l|}{ Content } \\
\hline $\begin{array}{l}\text { a) The content presented in the manual corresponds to } \\
\text { the objectives proposed }\end{array}$ & $7(63.6)$ & $4(36.4)$ & - & - & - \\
\hline $\begin{array}{l}\text { b) The content facilitates the teaching-learning process } \\
\text { in the topic }\end{array}$ & $8(72.7)$ & $3(27.3)$ & - & - & - \\
\hline c) The content allows understanding the topic & $10(90.9)$ & $1(9.1)$ & - & - & - \\
\hline d) The content follows a logical sequence & $8(72.7)$ & $3(27.3)$ & - & - & - \\
\hline $\begin{array}{l}\text { e) The content orderly incorporates all steps necessary } \\
\text { for teleassisting patients with } \mathrm{CIC}\end{array}$ & $7(63.6)$ & $4(36.4)$ & - & - & - \\
\hline $\begin{array}{l}\text { f) The content provides all material necessary to guide } \\
\text { the implementation of a } \mathrm{CIC}\end{array}$ & $7(63.6)$ & $3(27.3)$ & $1(9.1)$ & - & - \\
\hline
\end{tabular}




\begin{tabular}{|c|c|c|c|c|c|}
\hline Item & SA - N (\%) & $A-N(\%)$ & $D-N(\%)$ & SD - N (\%) & IDK - N (\%) \\
\hline g) The information presented by the manual is correct & $7(63.6)$ & $4(36.4)$ & & - & - \\
\hline h) The information presented by the manual is clear & $7(63.6)$ & $3(27.3)$ & $1(9.1)$ & - & - \\
\hline i) The information presented by the manual is objective & $7(63.6)$ & $4(36.4)$ & - & - & - \\
\hline $\begin{array}{l}\text { j) The images contained in the manual clearly illustrate } \\
\text { the content presented }\end{array}$ & $8(72.7)$ & $2(18.2)$ & $1(9.1)$ & - & - \\
\hline $\begin{array}{l}\text { k) The images contained in the manual illustrate } \\
\text { important aspects }\end{array}$ & $8(72.7)$ & $3(27.3)$ & - & - & - \\
\hline I) The images present adequate sharpness for viewing & $8(72.7)$ & $3(27.3)$ & - & - & - \\
\hline Total of answers ( $\mathrm{N}=132$ ) & $92(69.7)$ & $37(28.0)$ & $3(2.3)$ & - & - \\
\hline \multicolumn{6}{|l|}{ Language } \\
\hline a) The manual presents clear language & $7(63.6)$ & $3(27.3)$ & $1(9.1)$ & - & - \\
\hline b) The manual presents objective language & $9(81.8)$ & $2(18.2)$ & - & - & - \\
\hline $\begin{array}{l}\text { c) The manual presents language accessible to the } \\
\text { nursing staff }\end{array}$ & 7 (63.6) & $4(36.4)$ & - & - & - \\
\hline Total of answers ( $\mathrm{N}=\mathbf{3 3}$ ) & $23(69.7)$ & $9(27.3)$ & $1(3.0)$ & - & - \\
\hline \multicolumn{6}{|l|}{ Relevance } \\
\hline $\begin{array}{l}\text { a) The manual illustrates aspects that are important } \\
\text { for the practice of nursing teleassistance directed to } \\
\text { patients with NB }\end{array}$ & $8(72.7)$ & $3(27.3)$ & - & - & - \\
\hline $\begin{array}{l}\text { b) The manual is important to nurses for developing the } \\
\mathrm{CIC} \text {, guiding patients and caregivers }\end{array}$ & $9(81.8)$ & $2(18.2)$ & - & - & - \\
\hline $\begin{array}{l}\text { c) The manual allows transferring content learned and } \\
\text { generalizations to different contexts }\end{array}$ & $8(72.7)$ & $3(27.3)$ & - & - & - \\
\hline Total of answers ( $N=33$ ) & $25(75.7)$ & $8(24.3)$ & - & - & - \\
\hline \multicolumn{6}{|l|}{ Functionality } \\
\hline $\begin{array}{l}\text { a) The manual is a tool adequate given the objective for } \\
\text { which it was designed }\end{array}$ & $6(54.5)$ & $5(45.5)$ & - & - & - \\
\hline $\begin{array}{l}\text { b) The manual enables the generation of positive } \\
\text { outcomes in the teaching-learning process concerning } \\
\text { the topic }\end{array}$ & $8(72.7)$ & $3(27.3)$ & - & - & - \\
\hline Total answers ( $\mathrm{N}=\mathbf{2 2}$ ) & $14(63.6)$ & $8(36.4)$ & - & - & - \\
\hline \multicolumn{6}{|l|}{ Usability } \\
\hline a) The manual is user-friendly & 7 (63.6) & $4(36.4)$ & - & - & - \\
\hline $\begin{array}{l}\text { b) The manual is easy to understand and facilitates } \\
\text { assimilation of theoretical concepts and their } \\
\text { applications }\end{array}$ & $6(54.5)$ & $5(45.5)$ & - & - & - \\
\hline $\begin{array}{l}\text { c) The manual facilitates the application of concepts } \\
\text { into practice }\end{array}$ & $5(45.5)$ & $6(54.5)$ & - & - & - \\
\hline Total of answers $(\mathrm{N}=33)$ & $18(54.5)$ & $15(45.5)$ & - & - & - \\
\hline
\end{tabular}

SA: strongly agree; A: agree; D: disagree; SD: strongly disagree; IDK: I do not know. 
initiative in the field was the creation of a protocol to guide and regulate the practice of telenursing in the province of Nova Scotia. ${ }^{32}$ These documents are important references for the development of telehealth activities in Canada.

The group of experts who validated the telenursing manual in this study included nurses affiliated with different institutions located in different regions, which contributed to a greater variety of professional experiences. Various experts are professors or perform activities related to the field of research, most with a background in care delivery, while all of the experts reported direct or indirect involvement with the use of health technologies and/or in providing care to patients with $\mathrm{BN}$ using $\mathrm{CIC}$.

In regard to the degrees acquired by the experts, more than half had a doctoral degree, while the remaining had a Master's degree and most had some specialization. The experts rated highly based on the criteria proposed by Fehring, ${ }^{25}$ considering the field and the study's theme of interest.

One study involving the development and validation of a video script and video addressing the bandaging of central venous catheters also used the criteria proposed by Fehring to select experts and the scores reported ranged from 5 to 12 points. ${ }^{26}$

The experts' answers concerning the aspect "content" achieved $97.7 \%$ agreement, while there were three $(2.3 \%)$ disagreements concerning: lack of detail regarding information presented in flowchart 1 contained in the telenursing manual; the fact that some images did not present soap suds, which would represent improved hygiene; and a lack of detail regarding actions to take in the event of complications presented in the introduction of the catheter, for instance, if it is introduced in the vagina.

The experts' answers in regard to the aspect "language" obtained $97 \%$ agreement, while one (3.0\%) expert indicated a lack of detail in the information provided in the flowchart.

Inter-rater agreement obtained in regard to each aspect was: Language $97 \%$, Content $97.7 \%$, while Objectives, Functionality, Usability and Relevance achieved $100 \%$ each. Therefore, considering that the level of agreement achieved among the experts was greater than $70 \%$ for each aspect of the instrument, the telenursing was considered to have achieved apparent and content validity. ${ }^{27,28}$

The suggestions concerning the four experts' discordant responses were implemented in the final version of the telenursing manual. All other suggestions presented by the experts were assessed, and the main ones were implemented, for instance, the inclusion of images of patients introducing $\mathrm{CIC}$ while standing and sitting in a wheelchair and the inclusion of information concerning lubrication if the patient does not have a gel application nozzle. The suggestion to divide images concerning the procedure as performed in women and men was not considered, since half of the experts considered the way it was presented to be a positive.

\section{Assessment of the telenursing manual from the perspective of nurses}

The telenursing manual supported nurses in the last phase of the study, an intervention addressing telenursing in the care provided to patients with NB using CIC. ${ }^{33}$ The manual proved to be useful for professionals when teleassisting patients because it presents important information concerning the use of Orem's Self-Care Theory. ${ }^{22}$ The intervention also revealed, however, that effective teleassistance represents a challenge for nurses, considering that the theory has be adapted to the situation of teleassistance proposed.

The rationale for conducting teleassistance in accordance with the principles proposed by the College of Nurses of Ontario ${ }^{24}$ was essential for the structuring and implementing the telenursing intervention. For instance, a professional was asked to help when one of the nurses deemed it necessary, which met principle 3 - roles and responsibilities.

The technological resources used to aid teleassistance provided to patients with NB were compatible to this manual since e-mail, and especially telephone, was used.

In regard to guidance necessary to assist patients with $\mathrm{NB}$, the manual was efficacious because it presents the main information necessary to apply a CIC. It also revealed, however, that various other subjects concerning the needs of patients may emerge during assistance and nurses should be prepared to improvise and assist in the solution of these problems or, at least, be prepared to show the way for the patients themselves to solve these problems. In addition to guidance concerning the introduction of $\mathrm{CIC}$, other subjects are usually addressed in telenursing interventions implemented with patients, and therefore, require prior preparation on the part of nurses, as the following subjects are not included in the manual: signs of urinary infection; doubts regarding the face-to-face rehabilitation service where the patient receives treatment; doubts regarding urinary incontinence; and how to prepare for an ultrasound.

The conclusion from the monitoring of the use of the manual is that patients with NB present a challenge for health workers, considering the diversity of factors involved in treatment and rehabilitation. ${ }^{18,20}$ The manual is intended to provide nurses with a theoretical foundation upon which they can rely to develop telenursing directed to patients with NB to apply CIC, as well as to provide important information so nurses are able to structure telenursing services directed to other patients. Thus, for nurses to develop a teleassistance service directed to patients with NB and assist them in the implementation of $\mathrm{CIC}$, nurses should use the telenursing manual, in addition to continually seeking knowledge in order to be able to advise patients, responding to their doubts and meeting their needs that may emerge during teleassistance.

There is significant room for telenursing to evolve as a customer service strategy in Brazil. Since there is no legislation to support this type of service, we cannot test the manual among experienced nurses in the delivery of teleassistance. These 
professionals could observe from a different perspective how these themes were addressed in the manual.

\section{CONCLUSION}

Apparent and content validity was determined for the telenursing manual considering the level of agreement achieved among the experts and is a strategy with important tools to provide nurses a theoretical foundation for the development of teleassistance to patients with NB using CIC. It also provides important information for nurses to be able to structure teleassistance services for other patients. Nonetheless, for nurses to effectively provide teleassistance to patients with NB, various other materials should be used, while continually seeking knowledge, so that more references are accessed in the context of these patients and their pathology, in order to meet needs that may emerge during interviews with patients.

\section{ACKNOWLEDGEMENTS}

Appreciation for the financial support provided by the Coordination for the Improvement of Higher Education Personnel - CAPES, to the Vice-President for Research and University Extension - University of São Paulo, Brazil, and for the National Council for Scientific and Technological Development - CNPq.

\section{REFERENCES}

1. Schlachta-Fairchild LM, International Council of Nurses (ICN). International Competencies for Telenursing. Geneva: International Council of Nurses; 2007.

2. Maryam H, Robab A, Sara S. Functional capacity of heart failure patients fallowing the empowerment program based on telenursing in caregivers of patients: Randomized Clinical Trial. Int J Adv Biotechnol Res [Internet] 2017; [cited 2017 Jun 8]; 8(1):154-60. Available from: https://drive. google.com/file/d/0B8lgDBwl33UqOFIVczRiUF9FQkE/view

3. Hosseini MS, ZiaeiRad M. The impact of telenursing consultation by using the social networks to promote the self-efficacy and weight control in patients treating with hemodialysis. Int J Med Res Health Sci [Internet]. 2016; [cited 2017 Jun 8]; 5(12):52-9. Available from: http://www.ijmrhs. com/archive/ijmrhs-volume-5-issue-12-december-2016.html

4. Jelin E, Granum V, Eide H. Experiences of a Web-Based Nursing Intervention-Interviews with Women with Chronic Musculoskeletal Pain. Pain Manag Nurs [Internet]. 2012; [cited 2015 Jun 14]; 13(1):210. Available from: http://www.sciencedirect.com/science/article/pii/ S1524904211001792. DOI: 10.1016/j.pmn.2011.08.008

5. Hannan J. APN telephone follow up to low-income first time mothers. J Clin Nurs [Internet]. 2013 Jan; [cited 2015 Jun 25]; 22(1-2):262-70. Available from: http://onlinelibrary.wiley.com/doi/10.1111/j.13652702.2011.04065.x/epdf. DOI: 10.1111/j.1365-2702.2011.04065.x

6. Souza-Junior VD, Mendes IAC, Mazzo A, Godoy S. Application of telenursing in nursing practice: an integrative literature review. Appl Nurs Res [Internet]. 2016 Feb; [cited 2017 May 25]; 29:254-60. Available from: http://www.appliednursingresearch.org/article/S0897-1897(15)001032/pdf. DOI: 10.1016/j.apnr.2015.05.005

7. Kaminsky E, Carlsson M, Höglund AT, Holmström I. Paediatric health calls to Swedish telenurses: a descriptive study of content and outcome. J Telemed Telecare [Internet]. 2010; [cited 2017 May 25]; 16(8):4547. Available from: http://journals.sagepub.com/doi/pdf/10.1258/ jtt.2010.100110. DOI: 10.1258/jtt.2010.100110
8. Romero YMP, Angelo M, Muñoz Gonzalez LA. Imaginative construction of care: the nursing professional experience in a remote care service. Rev Latino-Am Enferm [Internet]. 2012 Jul/Aug; [cited 2015 May 23]; 20(4):693-700. Available from: http://www.scielo.br/scielo. php?script=sci_arttext\&pid=S0104-11692012000400009. DOI: 10.1590/S0104-11692012000400009

9. Mendes IAC, Godoy S, Seixas CA, Nogueira MS, Trevizan MA Alves LMM, Rangel EML, Mazzo A. Telenursing: Current Scenario and Challenges for Brazilian Nursing. In: Sajeesh K, Helen S, eds. Telenursing. New York: Springer; 2011. p. 17-27.

10. Brasil. Conselho Regional de Enfermagem de São Paulo. Orientação Fundamentada № 016/2017. Câmara Técnica; 2017 Available from: http://portal.coren-sp.gov.br/sites/default/files/ Orienta\%C3\%A7\%C3\%A30\%20Fundamentada\%20-\%20016_2.pdf

11. Lopes JL, Nogueira-Martins LA, Barbosa DA, Barros ALBL. Development and validation of an informative booklet on bed bath. Acta Pau Enferm [Internet]. 2013 Nov/Dec; [cited 2015 Jun 23]; 26(6):55460. Available from: http://www.scielo.br/scielo.php?pid=S010321002013000600008\&script=sci_arttext\&tIng=en. DOI: 10.1590/S010321002013000600008

12. Trigo-Rocha FE, Gomes CM. Bexiga Neurogênica. In: Nardozza Júnior A, Zerati Filho M, Reis RB, orgs. Urologia Fundamental. São Paulo: Planmark; 2010. p. 239-50. Available from: http://www.sbu-sp.org.br/ admin/upload/os1688-completo-urologiafundamental-09-09-10.pdf

13. Lenz LL. Cateterismo vesical: cuidados, complicações e medidas preventivas. ACM Arq Catarin Med [Internet]. 2006; [cited 2014 Jun 20]; 35(1):82-91. Available from: http://www.acm.org.br/revista/pdf/ artigos/361.pdf

14. Sociedade Brasileira de Urologia. Bexiga Urinária: Cateterismo intermitente. Projeto Diretrizes - Associação Médica Brasileira e Conselho Federal de Medicina; 2008. Available from: https://diretrizes. amb.org.br/_BibliotecaAntiga/bexiga-urinaria-cateterismo-intermitente. pdf

15. Lapides J, Diokno AC, Silber SJ, Lowe BS. Clean, intermittent selfcatheterization in the treatment of urinary tract disease. J Urol [Internet]. 1972 Mar; [cited 2014 Jun 23]; 107(3):458-61. Available from: https:// www.ncbi.nlm.nih.gov/pubmed/5010715

16. Webster J, Hood RH, Burridge CA, Doidge ML, Phillips KM, George N. Water or antiseptic for periurethral cleaning before urinary catheterization: a randomized controlled trial. Am J Infect Contro [Internet]. 2001 Dec; [cited 2015 Jan 20]; 29(6):389-94. Available from: https://www.ncbi.nlm.nih.gov/pubmed/11743486

17. Cheung K, Leung P, Wong YC, To OK, Yeung YF, Chan MW, et al. Water versus antiseptic periurethral cleansing before catheterization among home care patients: a randomized controlled trial. Am J Infect Control [Internet]. 2008 Jun; [cited 2015 Jan 28]; 36(5):37580. Available from: http://www.sciencedirect.com/science/article/pii/ S0196655307005305?via\%3Dihub. DOI: 10.1016/j.ajic.2007.03.004

18. Mazzo A, Souza Junior VD, Jorge BM, Fumincelli L, Trevizan MA, Ventura CAA, et al. Quality and safety of nursing care for patients using intermittent urinary catheterization. Esc Anna Nery [Internet]. 2017; [cited 2017 May 15]; 21(2):e20170045. Available from: http://www. scielo.br/scielo.php?pid=S1414-81452017000200216\&script=sci_ arttext\&tlng=en

19. Ramm D, Kane R. A qualitative study exploring the emotional responses of female patients learning to perform clean intermittent self-catheterisation. J Clin Nurs [Internet]. 2011 [cited 2016 May 15] 20(21-22):3152-62. Available from: https://www.ncbi.nlm.nih.gov/pub $\mathrm{med} /$ ?term $=\mathrm{A}+$ qualitative+study+exploring+the+emotional+respons es+of+female+patients+learning+to+perform+clean+intermittent+se If-catheterisation

20. Mazzo A, Souza-Junior VD, Jorge BM, Nassif A, Biaziolo CF, Cassini MF, et al. Intermittent urethral catheterization-descriptive study at a Brazilian service. Appl Nurs Res [Internet]. 2014 Aug; [cited 2015 May 10];27(3):170-4. Available from: https://www.ncbi.nlm.nih.gov/pubmed /?term=Intermittent+urethral+catheterization+-+descriptive+study+at+ a+Brazilian+service. DOI: 10.1016/j.apnr.2013.12.002 
21. Souza-Junior VD, Mendes IAC, Jorge BM, Mazzo A, Godoy S. Teleatendimento ao cliente usuário de cateterismo urinário intermitente limpo: ultrapassando fronteiras e integralizando o cuidado - Manual de telenfermagem. Ribeirão Preto: SOBRACEN; 2017. 92 p. Available from: http:// gruposdepesquisa.eerp.usp.br/gepecopen/publicacoes_livros.php

22. Echer IC. The development of handbooks of health care guidelines. Rev Latino-Am Enferm [Internet]. 2005 Sep/Oct; [cited 2016 Apr 10]; 13(5):754-7. Available from: http://www.scielo.br/scielo.php?script=sci_ arttext\&pid=S0104-11692005000500022. DOI: 10.1590/S010411692005000500022

23. Orem DE. Nursing: concepts and practice. 6th ed. St. Louis: Mosby;2001.

24. College of Nurses of Ontario (CNO). Telepractice: Practice Guideline. Toronto: CNO; 2017. 20 p. Available from: https://www.cno.org/ globalassets/docs/prac/41041_telephone.pdf

25. Fehring RJ. Methods to validate nursing diagnoses. Heart Lung [Internet]. 1987 Nov; [cited 2016 Apr 10]; 16(6 Pt 1):625-9. Available from: https://www.ncbi.nlm.nih.gov/pubmed/3679856

26. Ferreira MVF, Godoy S, Góes FSN, Rossini FP, Andrade D. Lights, camera and action in the implementation of central venous catheter dressing. Rev Latino-Am Enferm [Internet]. 2015 Jun; [cited 2017 Aug 22]; 23(6):1181-6. Available from: http://www.scielo.br/scielo. php?script=sci_arttext\&pid=S0104-11692015000601181\&lng=en DOI: 10.1590/0104-1169.0711.2664.

27. Grant JS, Davis LL. Selection and use of content expert for instrument development. Res Nurs Health [Internet]. 1997 [cited 2016 Apr 15]; 20(3):269-74. Available from: http://onlinelibrary.wiley.com/doi/10.1002/ (SICI) 1098-240X(199706)20:3\%3C269::AID-NUR9\%3E3.0.CO;2-G/full. DOI: 10.1002/(SICl)1098-240X(199706)20:3<269::AID-NUR9>3.0.CO;2-G
28. Polit DF, Beck CT. Nursing Research: Generating and Assessing Evidence for Nursing Practice. 9th ed. Philadelphia: Wolters Kluwer Health/Lippincott Williams \& Wilkins; 2012.

29. Cruz FOAM, Ferreira EB, Vasques CI, Mata LRF, Reis PED. Validation of an educative manual for patients with head and neck cancer submitted to radiation therapy. Rev Latino-Am Enferm [Internet]. 2016; [cited 2017 Apr 15]; 24:e2706. Available from: http://www.scielo.br/ pdf/rlae/v24/0104-1169-rlae-24-02706.pdf. DOI: 10.1590/15188345.0949 .2706

30. Ling CC, Lui LYY, So WKW. Do educational interventions improve cancer patients' quality of life and reduce pain intensity? Quantitative systematic review. J Adv Nurs [Internet]. 2012 Mar; [cited 2016 Jun 15]; 68(3):511-20. Available from: http://onlinelibrary.wiley.com/ doi/10.1111/j.1365-2648.2011.05841.x/epdf. DOI: 10.1111/j.13652648.2011.05841.x

31. National Initiative for Telehealth Guidelines. National Initiative for Telehealth (NIFTE) Framework of Guidelines. Ottawa: NIFTE; 2003. Available from: https://www.isfteh.org/files/work_groups/ FrameworkofGuidelines2003eng.pdf

32. College of Registered Nurses of Nova Scotia. Telenursing Practice Guidelines [Internet]. 2017 [cited 2017 Oct 17]. Available from: https:// crnns.ca/publication/telenursing-practice-guidelines/

33. Souza-Junior VD, Mendes IAC, Mazzo A, Godoy S, Santos CA Telenursing Intervention for Clean Intermittent Urinary Catheterization Patients: A Pilot Study. Comput Inform Nurs [Internet]. 2017; [cited 2017 Aug 21]; [Epub ahead of print]. Available from: http://journals.Iww.com/ cinjournal/Abstract/publishahead/Telenursing_Intervention_for_Clean_ Intermittent.99545.aspx DOI: 10.1097/CIN.0000000000000370 